Les bébés et les enfants porteurs de maladie cardiaque congénitale et spécialement les lésions obstructives (sténose aortique, sténose pulmonaire) méritent un commentaire: ils tolèrent mal la tachycardie qui accompagne l'atropinisation. Cependant, il faut remarquer que chez les tout jeunes enfants la réponse-tachycardie est beaucoup moins marquée que chez les patients plus âgés. Autre remarque, les patients avec maladie cardiaque congénitale seraient de bons candidats à ce régime à condition que l'on suive scrupuleusement les recommandations de Blanc et ses collaborateurs.

\title{
General anaesthesia in dentistry
}

The present day anaesthetist has seemingly forgotten, or chooses to ignore, that he owes his position in the medical world to two dentists, Horace Wells, who inhaled nitrous oxide for the painless extraction of an infected tooth and William Morton, who introduced anaesthesia with his demonstration that the inhalation of diethyl-ether allowed pain-free surgery.

The first use of ether for the painless extraction of a tooth was recorded in 1842 in Rochester, New York. Dr. Elijah Pope removed a tooth for a Miss Hobbie who had been given ether on a towel. The anaesthetist was a chemistry student, William Clarke, who had gained his experience by arranging ether frolics. ' Nathan Colley Keep, later Dean of Dentistry of Harvard, gave on April 7, 1848, intermittent ether inhalations to the wife of Henry Wadsworth Longfellow for her first delivery; this was the first recorded obstetrical anaesthesia in North America. ${ }^{2}$ The specialty of anacsthesia owes a great debt historically to the dental profession. In the 139 years since Horace Wells first inhaled nitrous oxide, an independent medical specialty has emerged and millions of patients every year benefit from surgical operations without pain. Many advances in technology, pharmacology and phy-

From the Department of Anaesthesia, University of Western Ontario, London, Ontario.

Address correspondence to: Dr. W.E. Spoerel, Department of Anaesthesia, University Hospital, P.O. Box 5339, Postal Station "A", London, Ontario, Canada N6A 5 A5. siology have since expanded anaesthesia but we are still relying on the discovery of the dentist from Hartford, Connecticut.

Unhappily, anaesthetists in turn have not shown much gratitude to the dental profession. Dental anaesthesia does not rank very high in the esteem of most anaesthetists and has little glamour. Much of the blame must go to tradition which has assigned irrationally the oral cavity to one profession and given the rest of the body to another. The medical profession has concentrated in hospitals where equipment and help are provided and, for the surgical patient, the required anaesthesia is also included at public expense.

Dentistry in its surgical and restorative aspect is almost entirely based on office practice. It is relatively recent that selected oral surgeons have gained access to the operating theatre where they are tolerated somewhat reluctantly. However, the vast majority of dentists have no access to hospitals and consequently are cut-off from the hospital based anaesthetist.

In his office the dentist is using his own equipment and has trained his office personnel to suit his style of practice. Dentists have developed their own approach to anaesthesia and employ regional anaesthesia and techniques of sedation with great skill. A few dentists have obtained training in giving general anaesthesia, but the dentist-anaesthetist has no official status amongst the medical anaesthetists. The result is that the patient who can readily get a safe general anaesthetic for a minor plastic surgical procedure, has to suffer through a much dreaded and more taxing and painful dental procedure 
without this benefit. The need for general anaesthesia in dentistry undoubtedly exists and if it were available, many more patients would request it. Not only would this relieve stress and anguish, particularly in children, but it would produce better working conditions for the dentist and allow extensive restorative and peridontal procedures to be carried out in one sitting, thus reducing the cost to the patient.

How can dental patients get better access to general anaesthesia? The dentist is reluctant to leave the comfort of his office where he can do good work with his own equipment in familiar surroundings. Likewise, the anaesthetist is unwilling to venture from the hospital operating room where he feels comfortable and safe amongst the complex technology he has assembled. Economic considerations favour this separation: the state will not provide for anaesthetic equipment outside the hospital nor equip special operating rooms inside the hospital to accommodate dentists.

One practical answer may be a dental office designed and equipped for the administration of general anaesthesia. Such offices have been provided by practicing dentists or groups of dentists; they have also been set up by dental anaesthetists who then invite other dentists to bring their patients to such an office for dental procedures under general anaesthesia. This solution requires considerable capital expenditure and enterprise if both the dentist and the anaesthetist are to be satisfied with the working conditions. The specialist anaesthetist who ventures from the operating room into an office will ask himself the question, is it safe to do this and should I be seen doing it?

With this question in mind, we learned of Dr. Kay's practice which represents yet another approach; general anaesthesia is provided in practically any dental office with the anaesthetist's own portable equipment. In this issue, Dr. Kay describes the organization of his practice, his selection of patients, anaesthetic technique, postoperative care and follow-up. Since he has practiced this approach to office anaesthesia successfully and safely, we encouraged him to report it in our Joumal. We believe anaesthetists have an obligation to provide dental anaesthesia. In our opinion, this paper reports an uncommon but successful and therefore possible approach which we hope will provoke reflection and constructive discussion.

\section{References}

1 Keys TE. The History of Surgical Anaesthesia, Dover Publications Inc., New York. 1963.

2 Notation: Boston Medical and Surgical Journal, April 14, 1848.

\section{Anesthésie générale en médicine dentaire}

Les anesthésistes contemporains semblent avoir oublié, ou préfèrent oublier, qu'ils doivent leur situation dans le monde médical à deux dentistes: Horace Wells, qui a inhale du protoxide d'azote lors de l'extraction sans douleur d'une dent infectée et William Morton, qui a ouvert la voie à l'anesthésie en démontrant que l'inhalation d'éther diéthylique permettait une chirurgie sans douleur.

La première administration d'éther pour extraction dentaire sans douleur d'une dent remonte à 1842 à Rochester, New York. Le Dr. Elijah Pope a alors extrait une dent d'une Mlle Hobbie qui avait préalablement reçu de l'éther imbibé sur une serviette. L'anesthésiste était un étudiant en chimie, William Clarke, qui avait déjà acquis une certaine expérience dans le domaine. Nathan Colley Keep, plus tard doyen de la faculté de médecine dentaire à Harvard, a administré des inhalations intermittentes d'éther, le sept avril 1848 à l'épouse de Henry Wadsworth Longfellow lors de son premier accouchement. C'est le premier exemple d'anesthésie obstétricale jamais enregistré en Amérique du Nord. Historiquement, la discipline de l'anesthésie doit beaucoup a la profession dentaire. Durant les 139 ans qui ont suivi la première inhalation de protoxide d'azote par Horace Wells, une nouvelle discipline indépendante est apparue et des millions de patients profitent chaque année d'opérations chirurgicales sans douleur. L'anesthésie s'est depuis développée grâce aux progrès de la technologie, de la pharmacologie et de la physiologie mais nous remonterons toujours à la découverte du dentiste de Hartford au Connecticut.

Malheureusement, les anesthésistes n'ont pas démontré beaucoup de gratitude à l'égard de la 